\title{
Sociolects and Registers - a Contrastive Analysis of Two Kinds of Linguistic Variation
}

\author{
Marcin Lewandowski \\ INSTYTUT JEZZYKOZNAWSTWA, UNIWERSYTET IM. ADAMA MICKIEWICZA \\ AL. NIEPODLEGŁOŚCI 4, 61-874 POZNAŃ \\ marcinleamu.edu.pl
}

\begin{abstract}
The paper, which is a theoretical contribution to investigations of social varieties of language, deals with two major dimensions of sociolinguistic variation: sociolectal and registerial. Drawing upon the views of Polish and Anglo-Saxon linguists, the author explores the concepts of sociolect (social dialect) and register, focusing mainly on their definitions, controlling variables, methodological frameworks, and typologies. In the final section, he attempts to shed some new light on the two kinds of variation and suggests new methodological solutions that could be applied in studies of sociolinguistic variation.
\end{abstract}

\section{Introduction}

'Anyone who wants to talk about the many varieties of a language is immediately faced with severe problems, the initial manifestations of which are largely terminological.'

(Zwicky and Zwicky 1982: 213).

The above quotation well illustrates a conceptual confusion with which a number of language variationists have had to struggle when attempting to name and define miscellaneous subsets of language. This terminological disarray, which may stem from the fact that social varieties are in flux, can be exemplified by the co-occurrence of such concepts as: variant, (social) variety, (social) dialect, special language, style, code, sublanguage, slang, cant, argot, jargon, and possibly a few others.

This paper does not aim to explore the above concepts one by one. Nor does it attempt to explain the differences among them. Instead, it deals with two perspectives on sociolinguistic variation: sociolectal and registerial. The former has gained considerable interest among Polish linguists; the latter has been explored mainly by Anglo-Saxon researchers. Even though the notions of sociolect and register seem to have been thoroughly investigated, there still remains some confusion about them. 
Thus besides reviewing the current state-of-the-art research into sociolects and registers, the paper intends to clarify the existing controversies and propose new methodological solutions.

\section{Sociolectal variation}

In Anglo-Saxon sociolinguistic thought (Holmes 2001; Hudson 1996; Romaine 2000; Trudgill 2003) the term sociolect ${ }^{1}$ is often used interchangeably with social dialect (the latter form seems to be more commonly used and preferred ${ }^{2}$ ). P. Trudgill defines it concisely as 'a variety or lect which is thought of as being related to its speakers' social background rather geographical background' (Trudgill 2003: 122). In other words, it is the language spoken by a particular social group, class or subculture, whose determinants include such parameters as: gender, age, occupation, and possibly a few others. Sociolect can be used then as a general term for some of the variety types referred to in the introductory section, and as such should be perceived as a handy label.

The notion of sociolect figures quite prominently in Polish sociolinguistic studies. By the late 1980 s (socio)linguistic research in Poland had centered on regional rather than on social varieties of the national language. However, with the rise of numerous social dialects (a consequence of the 1989 political and social upheaval), linguists focused more extensively on sociolects. At around the same time, the need for more extensive research into social dialects was also recognized by Hudson, who argued that people had been increasingly identifying with social rather than with regional groups and that especially in Britain 'social class takes precedence over geography as a determinant of speech (Hudson 1996: 42).

According to Wilkon (1989), who was the first to use the concept of sociolect in Polish sociolinguistic literature, sociolects are 'language varieties related to such social groups as: class, community and professional groups's (Wilkon 1989: 88). The term is meant to apply to colloquial varieties of Polish which are socially and functionally restricted. What distinguishes a sociolect from the standard variety is above all its lexical repertoire, which is activated in group-specific contexts. Wilkon also argues that the main prerequisite for a sociolect is the existence of a social group whose members maintain strong bonds (professional, social or cultural) established through frequent contacts with each other. If a sociolect is to evolve, the group of its users must be stable, have an established tradition, and display a sense of differentness from other groups.

\footnotetext{
${ }^{1}$ One of the first authors to use the term was J. Dillard in his monograph on Black English: 'Dialect refers to a set of features delimited geographically; sociolect to a socially distributed set' (Dillard 1972: 300).

${ }^{2}$ For reasons of style these two terms will be used interchangeably.

3 All translations of the Polish quotations have been performed by the author of this paper.
} 
Elaborating on Wilkon's ideas, Grabias (1994) argues that that the interdependence between language and society is more conspicuous in sociolects than in any other varieties of language. This is because a social group generates its own language (sociolect), and, simultaneously, the sociolect shapes and reinforces the group in question. To support this point, Grabias (1994: 117-118) lists a few group forming functions of social dialects. First of all, a sociolect links individuals with the community of its users and assigns prestige to a group. It also serves as an important identity marker, distinguishing thus a particular group from others. Lastly, and perhaps mainly, a sociolect, like every language, provides tools for interpreting reality, and imposes on its users a group-specific image of the world by strengthening the social values that a particular group holds dear. This function comes to the fore especially in the languages of violent groups: a violent group creates a violent language, which in turn consolidates the behavioral patterns of the group (Grabias 2001: 239).

Grabias's typology of Polish social dialects is based on three supreme sociolectal categories:

1. professionalism - the usefulness of linguistic devices in the professional activity of the group;

2. secrecy - the ability to code information to make it accessible only to selected individuals;

3. expressiveness - means of conveying attitudes to extra-linguistic reality (Grabias 1994: 127).

The nature of a sociolect is largely determined by two of these controlling variables: professionalism and expressiveness. As a result, in the first stage of catregorization social dialects can be arranged in two oppositions: occupational (professional) vs. non-occupational (nonprofessional) and expressive vs. non-expressive. Occupational varieties, according to Grabias, tend to be non-expressive, while expressive sociolects are lacking in the professionalism category.

Grabias (1994) claims that every sociolect includes strictly professional terminology as well as vocabulary referring to the human being and the world at large. Whether a particular social dialect should be classified as occupational or expressive depends on the proportions between professional and non-professional vocabulary. In the case of occupational varieties, a large portion of sociolectal vocabulary serves to label unlexicalized concepts, filling thus lexical gaps. Members of occupational groups make subtle lexical distinctions that are irrelevant to outsiders ${ }^{4}$. A distinctive feature of expressive sociolects, in turn, is the existence of sets of synonyms: new words and meanings are coined primarily to replace worn-out slang terms as well as convey humorous and ironical connotations rather than fill lexical gaps. Semantic precision gives way to attitudinal undertones (some of this vocabulary is emotionallyloaded). Grabias also argues that occupational varieties are marked by

4 For example, in the language of hunters we will find various terms denoting the legs of various animals. 
abbreviated communication while the vocabularies of expressive social dialects tend to be periphrastic5.

What we are left with is the last category, i.e. secrecy. Grabias (1994: 135) thinks that it is a constituent feature of all social varieties setting them apart from the standard and colloquial varieties of Polish. Every sociolect to a smaller or larger extent contains terminology which is incomprehensible to non-members of the social group which has generated that sociolect. In some social dialects their users may deliberately code information to make it inaccessible or incomprehensible to outsiders. Other varieties include words and phrases which may just be hardly communicative to ordinary people; however, their incomprehensibility is by no means intentional. Grabias (1994: 138) distinguishes then between intentionally coded and unintentionally coded sociolects.

What follows is a complete typology of Polish sociolects, proposed by Grabias (1994: 139), which is based on all three sociolectal categories (variables): professionalism, secrecy and expressiveness. Social dialects can accordingly be subdivided into:

1. occupational sociolects - dominated by the referential function:

a/ professional languages (uncoded) - professiolects, according to Wilkon (1989), in which language items are designed to convey thoughts in a precise and effective manner; e.g. the sociolects of hunters, soldiers or seamen;

b/ jargons (intentionally coded) - varieties used by groups excluded from society at large, such as criminals or prisoners ${ }^{6}$;

2. expressive sociolects 7 - dominated by the expressive function:

a/ slang (intentionally uncoded) - language items are designed to convey emotions or attitudes; e.g., students' or teenage slang;

b/ unintentionally coded varieties - created to experiment or play with language; e.g., children's secretive language.

An important contribution to the Polish theory of social dialects was also made by Kołodziejek (2006: 35-42). While embracing many of Grabias's ideas, she argues that nowadays it is difficult to delimit the boundaries between sociolects given the extent of social mobility (which applies in particular to young people). After all, most of us belong to a variety of groups (professional, peer, subcultural, hobby-based), and as we join new speech communities, we bring in some words and phrases and absorb new

\footnotetext{
5 In fact we will find abbreviated and periphrastic terms in all kinds of sociolects. Likewise both occupational and expressive social dialects will contain lexical gap fillers and new synonyms. Grabias (1994: 139) rightly claims that the occupational (or referential) and expressive functions co-exist in different proportions in every sociolect. What distinguishes these sociolectal types is the hierarchy of the three basic parameters.

${ }^{6}$ Halliday (1978: 164) calls such varieties antilanguages; they are meant to reflect the values of antisocieties.

7 For the sake of clarity, the names of the two basic categories have been simplified. More literally, they were respectively referred to as 'sociolects with a predominant professional and communicative function' and 'sociolects with a predominant expressive function'.
} 
ones. As a result, a great deal of sociolectal terminology is shared by various (sometimes socially remote) groups.

Coupled with that is another valid point concerning the sources of lexical repertoires of sociolects. Kołodziejek identifies three layers of sociolectal vocabulary:

1. colloquial language - the lexical base of all social dialects. This variety is generally understood and used by all native speakers of a particular language;

2. general slang vocabulary - used by young people regardless of their social group affiliation;

3. social group-specific vocabulary - lexical repertoire which is related to the kind of group activity. It is this layer of lexis which sets apart the varieties of different social groups, such as soldiers, seamen, hunters, etc.

In the final stage of her theoretical investigation Kołodziejek goes on to elaborate on the concept of subcultures. She makes a distinction between sociolects and languages of subcultures. While the former, just like slang or jargons, are associated solely with verbal behavior, the latter should be viewed as much broader concepts as besides the three lexical layers, they embrace typically subcultural attributes, i.e., the symbolic meaning of group-specific music, rituals, dress, tattoos, haircuts, etc. Thus besides the three layers of vocabulary discussed above, a subcultural language includes yet another one. Hence the communication process within a subculture displays greater complexity than in the case of a nonsubcultural group.

Finally, it needs to be emphasized that a social dialect generates an image of extra-linguistic reality. According to Grabias (1994: 140), a sociolect:

$>$ consolidates the interpretation of life experiences;

> shapes its users' attitudes to phenomena outside their social group;

$>$ frames a course of action for group members in relation to themselves, to other social groups, and finally to those components of reality that are of interest to the speakers of this sociolect.

Let us now demonstrate a sample methodology for sociolectal studies. A relevant framework combining social and linguistic perspectives was proposed by Piekot (2008: 39-49), who distinguished four fundamental research stages:

1. description of a relevant speech community ${ }^{-}$- this subsumes types of activity, social bonds that hold among group members, the

\footnotetext{
8 The term is used in a broad sense and designates such groups as soldiers, prisoners, soccer fans, hip hop followers, and even students.

9 Of numerous definitions of speech community I accept the one proposed by Gumperz (1971: 114): 'any human aggregate characterized by regular and frequent interaction by means of a shared body of verbal signs and set off from similar aggregates by significant differences in language use'. For more definitions see Hudson (1996: 24-26).
} 
community's relationship with and attitude to the outside world (mainstream society and other speech communities). At this stage, it is also necessary to identify all group-specific communication situations - on this basis, it will be relatively easy to determine relevant semantic categories (domains);

2. reconstruction of the linguistic image of the world - once the relevant material has been collected, it is necessary to recreate the linguistic image of the world (LIW) ${ }^{10}$ contained in it. This image is shaped by a particular community which experiences, interprets and evaluates components of the outside world. While reconstructing the LIW, an analyst has to determine the key elements of the reality (these will correspond to the lexico-semantic categories);

3. reconstruction of norms and values cherished by a particular community - according to Grabias (1994: 61), there are three sets of values which are central to sociolectal analysis: transcendental (good - evil), existential (life - death, happiness unhappiness), and cultural (welfare or harm of the human species, knowledge - ignorance, beauty - ugliness, conformity - nonconformity to customs);

4. formal analysis of a sociolect - this stage has to do with analysis of lexical features of a particular social dialect. An analyst classifies sociolect-specific vocabulary items depending on whether they are formal or semantic neologisms, and discusses their functions (nominative, stylistic, etc.). Under this approach, sociolectal analysis focuses mainly on vocabulary at the expense of other aspects of language.

It can hardly be denied that the above theory of sociolect constitutes the methodological cornerstone of the Polish research on social dialects. Above all, it provides valuable tools for analysis of social dialects, such as: 'clear classification criteria (the three controlling variables), precisely defined concepts and research methods' (Piekot 2008: 24). On the other hand, it is not free from a few drawbacks.

The most prominent one is what some linguists, including Grabias himself, would regard as an asset. The taxonomy is an attempt at systematizing a wide array of social varieties of the Polish language. However, such attempts are, by definition, doomed to failure given the wide range of social dialects which invariably permeate one another (Piekot 2008: 17). As a result, it is hard to identify autonomous sociolects and assign them unequivocally to a specific sociolectal category (e.g.,

10 The linguistic image of the world (Polish - językowy obraz świata) is one of the key concepts in Polish cognitive linguistics and sociolinguistic research. The concept, drawing on the views of Humboldt and Weisberger as well as cultural anthropologists (Malinowski, Sapir, Whorf), sees language as a tool for interpreting reality (cf. Bartmiński 2006). 
occupational or expressive). It would perhaps be more legitimate to locate particular sociolects along a continuum of varieties stretching from prototypically occupational to prototypically expressive social dialects. Another question is whether all occupational varieties exhibit sociolectal features. For example, it would be far-fetched to assume that doctors, car mechanics, or air-traffic controllers form close-knit communities who generate their own language with a group-specific image of the world ${ }^{11}$. What might also be treated as a source of controversy is the criterion of secrecy postulated by Grabias (1994) as one of the three sociolectal categories. As long as over 20 years ago Wilkon rightly argued that secrecy, being restricted primarily to criminal groups, which operate on the fringes of society, no longer plays a key role in contemporary communication - a view which nowadays seems even more valid. According to Wilkon (1989: 98), the sociolects of criminal groups (intentionally coded criminal jargons in Grabias's taxonomy) are not designed to conceal information but serve as a tool for reconstructing the image of the world. Finally, it seems that Grabias uses the term sociolect in a too broad and general sense. For example, he speaks of the 'sporting sociolect'. This would imply the existence of a group of athletes doing various sports but using one variety of language. This point will be dealt with more extensively in the final section of this paper.

\section{Registerial variation}

Register studies have gained considerable attention in Anglo-Saxon sociolinguistic thought (interestingly, the notion of register is practically non-existent in Polish sociolinguistic research ${ }^{12}$ ). According to de Beaugrande (1993) and Matthiessen (1993), the forerunner of the concept of register was the restricted language - a term coined by J. R. Firth, who defined it as a variety 'serving a circumscribed field of experience or action', which 'can be said to have its own grammar and dictionary' (Firth 1957: 87; 98).

Firthian ideas were further pursued by his disciple, the BritishAustralian linguist M.A.K. Halliday, who is credited to have introduced the term into mainstream linguistic discourse. He contrasted the concept of register with that of dialect, labeling the former as a variety according to the use, and the latter as a variety according to the user. In other words, 'a register is a variety defined by reference to the social context - it is a function of what you are doing at the time' while 'a dialect is a variety of a language that is defined by reference to the speaker: the dialect you speak is a function of who you are' (Halliday 1978: 157). A register is thus a

${ }^{11}$ It is perhaps due to this reason that in his taxonomy Wilkon (1989) singled out a separate category of professional varieties, which he termed professiolects. He also distinguished separate varieties related to such parameters as gender or age (biolects) or connected with psychical factors (psycholects)

${ }^{12}$ It is not even listed as a separate entry in the Polish-language Encyclopedia of General Linguistics (Encyklopedia Językoznawstwa Ogólnego 1999). 
Marcin Lewandowski: Sociolects and Registers - a Contrastive Analysis of Two Kinds of Variation

variety of language which corresponds to a variety of situation, and should be viewed as a semantic concept. 'Since it is a configuration of meanings, a register must also, of course, include the expressions, the lexicogrammatical and phonological features, that typically accompany or realize these meanings' (Halliday and Hassan 1991: 39).

Table 1 displays major differences between dialect and register.

Table 1. Dialects and Registers (Halliday 1978: 35)

\begin{tabular}{|c|c|}
\hline $\begin{array}{l}\text { Dialect ('dialectal variety') } \\
\text { = variety 'according to the user' }\end{array}$ & $\begin{array}{l}\text { Register ('diatypic variety') } \\
=\text { variety 'according to the use' }\end{array}$ \\
\hline $\begin{aligned} & \text { A dialect is: } \\
&>\text { what you speak (habitually) } \\
&>\text { determined by who you are } \\
& \text { (socio-region of origin and/or } \\
& \text { adoption), and } \\
&> \text { expressing diversity of social } \\
& \text { structure (patterns of social } \\
& \text { hierarchy) }\end{aligned}$ & $\begin{array}{l}\text { A register is: } \\
\text { what you are speaking (at } \\
\text { the time) } \\
\text { determined by what you are } \\
\text { doing (nature of social } \\
\text { activity being engaged in), } \\
\text { and } \\
>\text { expressing diversity of } \\
\text { social process (social } \\
\text { division of labor) }\end{array}$ \\
\hline $\begin{array}{l}\text { So in principle dialects are: } \\
\text { different ways of saying the same } \\
\text { thing } \\
\text { and tend to differ in: } \\
\text { phonetics, phonology, lexicogrammar } \\
\text { (but not in semantics) }\end{array}$ & $\begin{array}{l}\text { So in principle registers are: } \\
\text { ways of saying different things } \\
\text { and tend to differ in: } \\
\text { semantics (and hence in } \\
\text { lexicogrammar, and sometimes } \\
\text { phonology, as realization of this) }\end{array}$ \\
\hline $\begin{array}{l}\text { Extreme cases: } \\
\text { antilanguages, } \\
\text { languages }\end{array}$ & $\begin{array}{l}\text { Extreme cases: } \\
\text { restricted languages, languages for } \\
\text { special purposes }\end{array}$ \\
\hline $\begin{array}{l}\text { Typical instances: } \\
\text { subcultural } \\
\text { (standard/nonstandard) }\end{array}$ & $\begin{array}{l}\text { Typical instances: } \\
\text { occupational varieties (technical, } \\
\text { semi-technical) }\end{array}$ \\
\hline $\begin{array}{l}\text { Principal controlling variables: } \\
\text { Social class, caste; provenance } \\
\text { (rural/urban); generation; age; sex }\end{array}$ & $\begin{array}{l}\text { Principal controlling variables: } \\
\text { Field (type of social action); tenor } \\
\text { (role relationships); mode } \\
\text { (symbolic organization) }\end{array}$ \\
\hline $\begin{array}{l}\text { Characterized by: } \\
\text { Strongly-held attitudes towards } \\
\text { dialects as symbol of social diversity }\end{array}$ & $\begin{array}{l}\text { Characterized by: } \\
\text { major distinctions } \\
\text { spoken/written; language }\end{array}$ \\
\hline
\end{tabular}


action/language in reflection

A number of analysts, while generally subscribing to the traditional approach, under which registers are defined as situationally-conditioned varieties of language, have focused on different aspects of these varieties. For instance, Gregory and Carroll (1978: 64) view register as an example of language-in-action. Assuming a textual perspective, they argue that registers should be discussed in terms of 1) text-specific phonological, lexical and grammatical markers, and 2) common-core features, which are typical of all texts. Gregory and Carroll also stress the importance of cultural factors in the creation of registers 'since it is the culture of a society which determines the patterns of environments in which language can occur' (Gregory and Carroll 1978: 64).

Zwicky and Zwicky (1982) view register as a continuum. At one end there are classical cases of registers characterized by a strong correlation between linguistic and situtational factors. Examples include newspaper headlines, baby talk, and recipes. On the other end of the spectrum lie varieties exhibiting a relatively small number of features, such as the language of advertising, which the authors regard as a collection of various styles and registers.

According to Holmes (2001: 246), the term register can be understood in two ways. In a broader sense, it is a variety of language associated with such situational parameters as: addressee, setting, mode of communication, task or topic. However, some researchers apply the term to refer to the specific vocabulary employed by various occupational groups or used in specific situations. The narrower definition of the concept seems rather unacceptable since, as has already been suggested and will be stressed further, register analysis should not be solely restricted to vocabulary. Register studies should include (and, in fact, most of them do include) other aspects of language as well. As Ferguson (1994: 20) once put it, 'people participating in recurrent communication situations tend to develop similar vocabularies, similar features of intonation, and characteristic bits of syntax and phonology that they use in these situations'.

Wardhaugh emphasizes a different aspect of registers, referring to them as 'sets of language items associated with discrete occupational or social groups' (Wardhaugh 2002: 51). It is certainly true that a number of studies have focused on the registers employed by specific groups such as, for example, sports announcers (Ferguson 1983), students (Reppen 2001), researchers (Conrad 2001), or even parents speaking baby talk (Ferguson 1977). Nevertheless, the concept is strongly associated with situations of use rather than with specific groups of individuals, which is why Wardhaugh's definition is difficult to accept.

The vagueness of the term register coupled with definitional confusion has led to numerous discussions among linguists, some of whom have argued for alternative concepts. For example, Crystal and Davy (1969), 
sound highly critical of the notion of register, which they find obscure, general and overused:

'This term has been applied to varieties of language in an almost indiscriminate manner, as if it could be usefully applied to situationally distinctive pieces of language of any kind. The language of newspaper headlines, church services, sports commentaries, popular songs, advertising, and football, amongst others, have all been referred to as registers in one work. [...] it is inconsistent, unrealistic, and confusing to obscure these differences by grouping everything under the same heading.' (Crystal and Davy 1969:61).

O'Donnel and Todd also challenged the concept of register on the grounds of its obscurity, arguing that the promise of precision implied by the register approach is ultimately unhelpful' (O'Donnel and Todd 1992: 65). They claim that a constellation of situational factors does not yield a particular register and that it is impossible to delineate discreet registers. Instead, the writers propose to apply the term style to describe situationally-conditioned varieties.

From today's perspective, the above criticism is totally unjustified. Firstly, thanks to a consistently developed methodological framework, register is anything but an obscure concept. Secondly, as Zwicky and Zwicky (1982) argue convincingly, style is a completely different dimension of linguistic variation from register. After all, the same register may exhibit stylistic variation. For example, church sermons, news headlines or academic lectures tend to vary in the degree of formality ${ }^{13}$. As Wardhaugh (2001: 51) points out, 'dialect, style and register differences are largely independent: you can talk casually about mountain climbing in a local variety of a language, or you can write a formal technical study of wine making'.

Perhaps the most convincing explanation of the differences between register, style and genre was offered by Biber and Conrad (2009) in their monograph on the three language varieties. Of great merit is the authors' approach to these concepts: they associate them with three different perspectives. As shown below, these perspectives differ in terms of: (1) the texts for the analysis, (2) the linguistic characteristics for the analysis, (3) the distribution of these characteristics within the texts, and (4) the interpretation of the linguistic differences.

Table 2. Defining characteristics of registers, genres and styles.

\begin{tabular}{|l|l|l|l|}
\hline $\begin{array}{l}\text { Defining } \\
\text { characteristic }\end{array}$ & Register & Style \\
\hline Textual focus & Sample of text & Complete texts & Sample of text \\
\hline
\end{tabular}

${ }_{13}$ Obviously, some registers show statistical preference for formal or informal style. 
Investigationes Linguisticae, vol. $X X$

\begin{tabular}{|l|l|l|l|}
\hline $\begin{array}{l}\text { Linguistic } \\
\text { characteristics }\end{array}$ & $\begin{array}{l}\text { Any lexico- } \\
\text { grammatical } \\
\text { feature }\end{array}$ & $\begin{array}{l}\text { Specialist lexico- } \\
\text { expressions, } \\
\text { rhetorical } \\
\text { organization, } \\
\text { formatting }\end{array}$ & $\begin{array}{l}\text { Any ants } \\
\text { grammatical } \\
\text { feature }\end{array}$ \\
\hline $\begin{array}{l}\text { Distribution of } \\
\text { linguistic } \\
\text { characteristics }\end{array}$ & $\begin{array}{l}\text { Frequent and } \\
\text { pervasive in texts } \\
\text { from the variety }\end{array}$ & $\begin{array}{l}\text { Usually once- } \\
\text { occurring in the } \\
\text { text, in a } \\
\text { particular place } \\
\text { in the text in } \\
\text { pervasive in } \\
\text { texts from the } \\
\text { variety }\end{array}$ \\
\hline Interpretation & $\begin{array}{l}\text { Features serve } \\
\text { important } \\
\text { communicative } \\
\text { functions in the } \\
\text { register }\end{array}$ & $\begin{array}{l}\text { Features are } \\
\text { conventionally } \\
\text { associated with } \\
\text { the genre: the } \\
\text { expected format, } \\
\text { but often not } \\
\text { functional }\end{array}$ & $\begin{array}{l}\text { Features are not } \\
\text { directly } \\
\text { functional; they } \\
\text { are preferred } \\
\text { because they are } \\
\text { aesthetically } \\
\text { valued }\end{array}$ \\
\hline
\end{tabular}

Source: Biber and Conrad (2009: 16)

At the core of the register perspective lies the assumption that the linguistic features of texts are functional, i.e. they are analyzed in connection with the communicative purposes and situational context of texts (analyzed as samples). The genre perspective also takes into account the purposes and context of a text variety but the focus of the linguistic analysis is on conventional structures that appear in a complete text. Contrary to the register perspective, the functional aspect is non-existent. By contrast, the style perspective shares with the register perspective its linguistic focus on typical lexico-grammatical features within a variety. However, just like the genre approach, it excludes functional motivation from the spectrum of interest. Linguistic features are interpreted in terms of the authors' aesthetic preferences.

Developing a comprehensive methodological framework for register analysis proved to be a demanding task. Ferguson identified two approaches to register variation: the parameter approach and the label approach. The former is based on 'a taxonomic grid of several major dimensions or parameters, such as field, mode, participants, tenor, and so forth' (Ferguson 1983: 155). Under the latter perspective, researchers should merely label and describe the register in question without trying to locate it within a taxonomy of other registers of the same language. According to Ferguson, both of these stances have some flaws: the parameter approach sometimes proves unsatisfactory as register features and markers cannot always be discussed in terms of a restricted set of parameters; the label approach, in turn, 'offers no general framework for 
the total pattern of register variation in a single language or speech community or for comparisons between languages or communities or for “universals" of register variation' (Ferguson 1983: 155).

One of the most significant frameworks for situational determinants of register was developed by Halliday (1978: 33, 62-64). Every register is determined by three controlling variables: field, mode and tenor. Field involves the setting in which communication takes place, and includes the purpose and subject matter or topic of the communication process. Mode refers to the channel or medium of communication; in other words, the choice between speech and writing. Finally, tenor indicates the relationship between the speaker and the addressee. Gregory and Carroll (1978:51-54) distinguish between two kinds of tenor: 1) personal, which reflects the formality level of the situation, and 2) functional, which roughly corresponds to the illocutionary aspect of communication as it focuses on the function of language in a specific situation. It needs to be remembered that these variables are mutually dependent; e.g., the field of discourse can determine the channel (mode) and the degree of formality (tenor).

This triadic construct was soon replaced by more elaborate frameworks that were applied in register studies. What follows is one of the most recent and comprehensive frameworks to date, which was postulated by Biber and Conrad (2009). Also applicable to genre analysis, it is based on earlier proposals, notably: Hymes (1974), Halliday (1978), and Biber (1988, 1994). Biber and Conrad (2009: 40-47) have proposed the following set of situational characteristics of registers and genres.

\section{Participants}

A. Addressor(s) (i.e. speaker or author)

1. single / plural / institutional / unidentified

2. social characteristics: age, education, profession, etc.

B. Addressees

1. single / plural / un-enumerated (e.g., radio broadcast listeners, TV show viewers, book readers, etc.)

2. self / other

C. Are there on-lookers?

The category of participants (addressors and addressees) requires hardly any explanation. What needs to be remembered is that the social characteristics of the person (or people) producing the text have a pronounced impact on language choices. Also essential is the role of onlookers, i.e. participants who are not direct addressees of the text (e.g., a theater audience watching a dramatic play).

\section{Relations among participants}

A. Interactiveness

B. Social roles: relative status or power

C. Personal relationship: e.g., friends, colleagues, strangers

D. Shared knowledge: personal and specialist 
The degree of interactiveness varies from register to register. Conversations, for example, are highly interactive; on the other end of the spectrum we come across such pieces of writing as catalogs with which any interaction is hardly possible. Social roles and personal relationships roughly correspond to the personal tenor in Halliday's framework. Finally, registers can display variation depending on the degree of shared background knowledge (e.g. academic writings vs. popular science publications).

\section{Channel}

A. Mode: speech / writing / signing

B. Specific Medium: mail, etc.

Permanent: taped / transcribed / printed / handwritten / e-

Transient speech: face-to-face / telephone / radio / TV / etc.

Channel is synonymous with Halliday's mode and concerns the distinction into spoken and written texts ${ }^{14}$.

IV. Production circumstances: real time / planned / scripted / revised and edited

Production circumstances are strictly related to the channel of communication. In the case of spoken registers there is hardly any room for editing language. Written texts definitely allow greater editing opportunities though they will vary in this respect depending on the genre.

\section{Setting}

A. Is the time and place of communication shared by participants?

B. Place of communication

1. Private / public

2. Specific setting

C. Time: contemporary, historical time period

The setting (i.e. the time and place of interaction) has a pronounced impact on language choices depending on whether communication takes place in a private or public place (shared or not shared by the participants), or whether it is set in a historical or contemporary period.

\section{Communicative purposes}

A. General purposes: narrate / report, describe, exposit / inform / explain, persuade, how-to / procedural, entertain, edify, reveal self

B. Specific purposes: e.g., summarize information from numerous sources, describe methods, present new research findings, teach moral through personal story

C. Factuality: factual information, opinion, speculative, imaginative

D. Expression of stance: epistemic, attitudinal, no overt stance

${ }^{14}$ However, not all registers are solely spoken or written. Biber and Conrad (2009: 43) provide examples of more restricted registers such as drum talk or smoke signals. 
The general purposes of communication are relatively easy to identify. However, as Biber and Conrad rightly argue, within one register it is possible to discern more than one communicative purpose (e.g., textbooks include descriptive and explanatory purposes). Specific purposes will also influence language choices to the extent that within the same text it is possible to identify distinct subregisters (e.g., different sections in a research paper). Factuality is an important determinant of particular genres, which also differ in regard to the expression of stance ${ }^{15}$.

\section{Topic}

A. General topical "domain": e.g., domestic, daily activities, business / workplace, science, education / academic, government / legal / politics, religion, sports, art/ entertainment, etc.

B. Specific topic

C. Social status of person being referred to (e.g. in Japanese)

Topic, which roughly corresponds to Halliday's field, is the most important determinant of lexical choices (this applies to both general and specific topics). According to Biber and Conrad (2009), topic has hardly any impact on the grammar of a register. Grammatical differences among registers are more related to the previous criterion: they arise as a result of different communicative purposes.

According to Biber and Conrad (2009: 47) a register analysis involves three steps: '(1) describing the situational characteristics of the register; (2) analyzing the typical linguistic characteristics of the register; and (3) identifying the functional forces that help to explain why those linguistic features tend to be associated with those situational characteristics'. Having discussed the situational determinants of registers, let us now elaborate upon the most common or typical linguistic features that are considered in register analysis.

The key question, however, is which lexico-grammatical features are typical or characteristic of a particular register. Biber and Conrad (2009) offer a solution to this problem by postulating three perspectives in register studies. We will discuss them briefly one by one:

The first one is the need for a comparative approach. According to Biber and Conrad, by comparing samples of texts from different registers, it is possible to determine whether particular features (use of nouns, pronouns, verbs, etc.) are characteristic of the target register. While discussing the linguistic characteristics of registers, Biber and Conrad introduce two vital concepts, namely register features and register markers. The former are defined as 'words or grammatical characteristics that are (1) pervasive - distributed throughout a text from the register, and (2) frequent - occurring more commonly in the target register than in

${ }^{15}$ For example, a newspaper report of an event typically does not contain any overt stance. Epistemic stance, in turn, is a marker of science articles, while attitudinal stance (personal opinions) can be found in reviews, editorials, etc. 
most comparison registers.' (Biber and Conrad 2009: 53) ${ }^{16}$. Register markers, in turn, are those linguistic features (mostly specific words and phrases) that are specific to the target register, i.e. they do not appear in other registers ${ }^{17}$.

The second consideration mentioned by Biber and Conrad is the need for quantitative analysis. In this perspective it is necessary to determine the extent to which a given register feature occurs in the target register. Of course, most linguistic features can be found in almost all registers (e.g., passive structures). Hence, quantitative analysis should be combined with a comparative approach. Otherwise, a register analyst would have no way of knowing whether a particular word, construction, or a grammatical class is pervasive or frequent enough to be considered a register feature.

The third and final aspect is the need for a representative sample of texts. A natural question that occurs here is: what actually constitutes a representative sample? There is no easy answer to this question. According to Biber and Conrad (2009), the size of text corpus will vary depending on the type of characteristics to be investigated (i.e., if an analyst wants to make legitimate claims about less frequent features, they will have to investigate a larger sample of texts).

Biber and Conrad (2009: 78-82) also provide a comprehensive list of linguistic features to be investigated in register studies. Sample categories include: vocabulary features (e.g., specialized words, vocabulary distributions), function word classes (e.g., pronouns, prepositions, discourse markers), voice (passive, active), noun phrases (e.g., semantic categories, determiner/article use, nominal post-modifiers), adverbials (e.g., stance adverbial types, adverbial clause types), special features of conversation (e.g., backchannels, and simple responses).

How is a quantitative register analysis conducted? An analyst computes rates of occurrences of a particular linguistic feature in a text sample. Since texts vary in size, it is necessary to arrive at "normed" rates of occurrence (Biber and Conrad 2009: 62) - in other words, the frequency of occurrence of a particular feature in a text sample, which usually includes 100 words. To perform such conversions, the following formula should be applied:

Normed rate $=($ raw count $/$ total word count $) \mathrm{x}$ the fixed amount of text ${ }^{18}$

\footnotetext{
${ }^{16}$ An example of a register feature is the passive voice in the register of academic writing. Passive verbs occur in various proportions in other registers, yet they are definitely a distinctive feature of academic texts.

${ }_{17}$ For example, the register of baseball sportscasting will immediately be identified by the occurrence of such terms as sliding into second, or the count is three and two, which can hardly be found outside baseball contexts (cf. Ferguson 1983).

${ }_{18}$ To supply an example, if a sample text with a total word count of 173 words includes 4 demonstrative pronouns, then the normed rate of occurrence for this grammatical category is 2.31 per 100 words.
} 
The final and perhaps the most intriguing step of a register analysis involves functional interpretation. At this stage, an analyst has to explain why the selected linguistic features are related to the situational characteristics and supply relevant examples of usage. As Biber and Conrad (2009: 69) argue, 'several linguistic features will usually have a common functional interpretation. Similarly, several different situational characteristics can be associated with a single linguistic characteristic.' The authors also provide a list of situational characteristics which are functionally linked to specific linguistic features (2009: 68). For example, interactivity is expressed by means of questions and $1^{\text {st }}$ and $2^{\text {nd }}$ person pronouns; personal stance is conveyed by the use of possibility adverbs, personal pronoun + mental or desire verbs; referring to shared personal knowledge involves the use of pronouns, first names of friends, vague references (e.g., thing).

Finally, let us address the question of register typologies. There are hardly examples of register taxonomies - a point emphasized by various researchers. Ferguson (1983) in the concluding section of his paper on sports announcer talk argues that it is difficult to delineate particular register types. 'Few people [...] hold high hopes that a rigorous typology will appear soon, and fewer still would insist that research cannot proceed without one' (de Beaugrande 1993: 16). However, some analysts have attempted to propose dichotomous distinctions between register types.

Halliday and Hassan (1991: 39-42) make two such distinctions. They divide registers into action-oriented and talk-oriented. The former are characterized by the prevalence of non-linguistic activity - there is very little talk and a lot of action (e.g., various kinds of instructions: coaching, cooking, etc.). Thus they have been alternatively labeled as languages in action. In the latter type most of the activity is essentially linguistic (e.g., a university lecture). In other words, 'the social activity of the linguistic event can change although the field remains the same. The activity can be placed on a "more" or "less" linguistic cline' (Gregory and Carroll 1978: 72). Finegan and Biber make a similar distinction - they argue that registers display variation in accordance to different communicative needs. 'Some situations require more explicitness; others tolerate greater economy' (Finegan and Biber 1994: 321). The former exhibit preference for the clarity mandate, the latter for the ease mandate. Academic prose, which is lacking in interactional elements, favors the clarity mandate. As examples of the second kind of registers, Finegan and Biber mention conversations, which rely heavily on the socio-pragmatic context in which they occur. Naturally, as is usually the case with such distinctions, hardly any registers can be assigned outright to a specific category; it is thus legitimate to speak of registers arranged along a continuum from 'highly explicit' to 'highly economical'.

Another distinction made by Halliday and Hassan (1991: 39-40) has to do with the total number of meanings conveyed. Hence, at one end, there are closed registers, where the number of meanings is small and fixed. Examples include the International Language of the Air, secretive 
languages of military forces or the language of menus. In such varieties, 'there is no scope for individuality, or for creativity' (Halliday and Hassan 1991: 39). On the other end of the spectrum we have open registers, which definitely outnumber restricted languages, and are much less constrained when it comes to lexico-grammatical choices (e.g., the registers of instructions, transactional registers, and many others). An extreme example of an open-ended register is spontaneous conversation where a range of possible meanings is practically unlimited.

\section{Conclusion}

At first glance it seems that the terms sociolect and register refer to similar, if not the same, subsets of language. However, as has been demonstrated, these two concepts accentuate different aspects of language. It has been argued that sociolect is strongly associated with specific social groups (people sharing the same occupation, hobby, or ideology in the case of subcultures). It needs to be re-emphasized that this kind of variation occurs (at least by definition) only if the language of a specific social group serves as an identity marker for this group. It seems though that sometimes the term is used overbroadly to designate varieties that do not meet these requirement. While it is definitely true that most of us can handle several language varieties, it is debatable whether all of them can be labeled as sociolects. It appears that only some social groups boast an established tradition, which is one of the prerequisites for a sociolect. Thus it would be fair to restrict this term to close-knit communities or hobby-based groups, such as: hunters, soldiers, seamen, subcultural groups, and possibly a few others.

By contrast, a register is defined as a situationally-conditioned variety, and as such is strongly linked with a situation calling for the use of specific language. While registers can facilitate communication, they relate primarily to particular occasions rather than to specific social groups ${ }^{19}$. Let us take as an example the language of soccer sportscasters, which exhibits a number of easily identifiable features. It would be far-fetched to argue that this language variety serves as an identity marker for its speakers. The language of soccer players and coaches also exhibits the characteristics of a register (cf. Lewandowski 2008). The language choices they make are determined largely by the situational context, rather than by the need to identify with their occupational group.

Halliday's distinction into dialects (which share many characteristics with sociolects) and register goes back to the 1970s. Under this approach, a dialect was defined as a habitual language variety. However, whether this is still true is debatable. Even Halliday himself was skeptical about his own claim, as he argued that 'a dialect is with us all our lives - it is not subject to choice. In practice, however, this is less and less true, and the

${ }^{19}$ Interestingly, a register and a sociolect can co-exist side by side in some areas of life, e.g. in armed forces: the military register (the language of regulations and instructions) and army slang (an informal variety used by soldiers). 
phenomenon of "dialect switching" is widespread. Many speakers learn two or more dialects, either in succession, dropping the first when they learn the second, or in coordination, switching them according to the context of situation. Hence the dialect comes to be an aspect of register' (Halliday 1978: 34).

We have now come to a major point. Far from discarding the theory of sociolect, we can assume that the theory of register serves as a better tool for language variation analysis, as it mirrors the nature of today's communication. As Wardhaugh argues:

\begin{abstract}
'[...] at any moment, an individual locates himself or herself in social space according to the factors that are relevant to him at that moment. While he or she may indeed have certain feelings about being a member of the lower middle class, at any moment it might be more important to be female, or to be a member of a particular church or ethnic group, or to be an in-patient in a hospital, or to be a sister-in-law. That is, selfidentification or role-playing may be far more important than some kind of fixed social-class labeling.' (Wardhaugh 2002: 149)
\end{abstract}

It should also be emphasized that sociolect and register studies rely on different methodological frameworks. In the case of sociolects, researchers primarily look for distinctive features of vocabulary and try to reconstruct the linguistic image of the world contained in group-specific terminology. Register analysts, in their search for connections between linguistic and situational features, attempt to obtain a broader picture of the variety they are investigating, focusing on a wide range of lexico-grammatical features (e.g., discourse features, tense usage, distribution and frequency of occurrence of particular grammatical categories, etc.). As regards spoken registers, the scope of research may also include phonological aspects.

However, if these two different methodological approaches could at least be partially combined, studies of social varieties would perhaps yield even more interesting insights. Sociolectal analysis might then incorporate a functional interpretation of a wide range of linguistic features. Registerial analysis could, in turn, also involve the reconstruction of the linguistic image of the world generated by the lexico-grammatical features in a given register (e.g., this could be achieved through the analysis of metaphors). An upcoming monograph on the language of soccer by the author of this paper aims to combine the two perspectives.

\title{
References
}

Bartmiński, J. 2006. Językowe podstawy obrazu świata. Lublin: Wydawnictwo Uniwersytetu Marii Curie-Skłodowskiej.

de Beaugrande, R. 1993. "Register" in discourse studies: a concept in search of a theory. in: M. Ghadessy (Ed.) Register Analysis. Theory and Practice. London and New York: Printer Publishers. pp. 7-25. 
Biber, D. 1988. Variation Across Speech and Writing. Cambridge: Cambridge University Press.

Biber, D. 1994. An Analytical Framework for Register Studies. in: D. Biber, E. Finegan (Eds.) pp. 31-56.

Biber, D., Conrad S. 2009. Register, Genre and Style. Cambridge: Cambridge University Press.

Biber D., Finegan E. (Eds.) 1994. Sociolinguistic Perspectives on Register. New York and Oxford: OUP.

Conrad, S. 2001. Variation among disciplinary textbooks and journal articles in biology and history. in: S. Conrad, D. Biber (Eds.) pp. 94-107.

Conrad, S., Biber D. (Eds.) 2001. Variation in English: Multi-Dimensional Studies. Harlow, England: Longman.

Crystal, D., Davy D. 1969. Investigating English Style. London: Longman.

Dillard, J. L. 1972. Black English: Its History and Usage in the United States. New York: Vintage Books.

Ferguson, C. 1977. Baby talk as a simplified register. in: C.E. Snow, C. Ferguson (Eds.) Talking to children. Cambridge: CUP. pp. 209-235.

Ferguson, C. A. 1983. Sports Announcer Talk: Syntactic aspects of register variation. Language in Society 12. pp. 153-172.

Ferguson, C. 1994. Dialect, Register, and Genre: Working Assumptions About Conventionalization. in: D. Biber, E. Finegan (Eds.). pp. 15-30.

Finegan, E., Biber D. 1994. Register and Social Dialect Variation: An Integrated Approach. in: D. Biber, E. Finegan (Eds.) pp. 315-347.

Firth, J.R. 1957. Papers in Linguistics 1934-1951. London: Oxford University Press.

Grabias, S. 1994. Język $w$ zachowaniach społecznych. Lublin: Wydawnictwo Uniwersytetu Marii Curie-Skłodowskiej.

Gregory, M., Carroll S. 1978. Language and Situation: Language Varieties and their Social Contexts. London, Boston: Routledge and Kegan Paul.

Gumperz, J. J. 1971. Language in Social Groups: Essays Selected and Introduced by Anwar S. Dil. Stanford, California: Stanford University Press.

Halliday, M.A.K. 1978. Language as Social Semiotic: the social interpretation of language and meaning. London: Edward Arnold.

Halliday, M. A. K., Hasan R. 1991. Language, Context and Text: Aspects of Language in a Social-Semiotic Perspective. Oxford: OUP.

Holmes, J. 2001. An Introduction to Sociolinguistics. Harlow: Pearson Education.

Hudson, R. A. 1996. Sociolinguistics. Cambridge: CUP.

Hymes, D. 1974. Foundations in sociolinguistics: an ethnographic approach. Philadelphia: University of Pennsylvania Press.

Kołodziejek, E. 2006. Człowiek $i$ świat $w$ języku subkultur. Szczecin: Wydawnictwo Naukowe Uniwersytetu Szczecińskiego.

Lewandowski, M. 2008. The Language of Soccer - a Sociolect or a Register? in: P. Nowak, P. Nowakowski (Eds.) Język, Komunikacja, Informacja 3. Poznań: Sorus. pp. 21-32.

Matthiessen, C. 1993. Register in the round: diversity in a unified theory of register analysis. in: M. Ghadessy (Ed.) Register Analysis. Theory and Practice. London and New York: Printer Publishers. pp. 221-292.

O’Donnel, W.R., Todd L. 1992. Variety in Contemporary English. London, New York: Routledge. 
Marcin Lewandowski: Sociolects and Registers - a Contrastive Analysis of Two Kinds of Variation

Piekot, T. 2008. Język $w$ grupie spolecznej. Wprowadzenie do badań socjolektów. Wałbrzych: Państwowa Wyższa Szkoła Zawodowa im. Angelusa Silesiusa w Wałbrzychu.

Reppen, R. 2001. Register variation among disciplinary textbooks and journal articles in biology and history. in: S. Conrad, D. Biber (Eds.) pp. 187-199.

Romaine, S. 2000. Language in Society: an introduction to sociolinguistics. Oxford: OUP.

Trudgill, P. 2003. A Glossary of Sociolinguistics. Edinburgh: Edinburgh University Press.

Wardhaugh, R. 2002. An Introduction to Sociolinguistics. Oxford: Blackwell.

Wilkoń, A. 1989. Typologia odmian językowych współczesnej polszczyzny. Katowice: Wydawnictwo Uniwersytetu Śląskiego.

Zwicky, A., Zwicky A. 1982. Register as a Dimension of Sociolinguistic Variation. in: R. Kittredge, J. Lehrberger (Eds.) Sublanguage: Studies of Language in Restricted Semantic Domains. Berlin, New York: W. de Gruyter. pp. 213-218. 